Postgraduate Bosowa University Publishing (PBUP)
Indonesian Journal of Business and Management
e-ISSN: $2460-3767 \quad p$-ISSN: $2656-6885$
INttps://postgraduate.universitasbosowan
JOURAL

\title{
ANALISIS DETERMINAN KINERJA PEGAWAI PADA BADAN KEPEGAWAIAN DAN PENGEMBANGAN SUMBER DAYA MANUSIA (BKPSDM) KABUPATEN JENEPONTO
}

\author{
Analysis of the Determinants of Employee Performance at the Personnel and Human Resources \\ Development Agency (BKPSDM) Jeneponto Regency
}

\author{
Muhammad Ichsan M. Nur ${ }^{1}$, Firman Menne ${ }^{1}$, Seri Suriani ${ }^{1}$ \\ ${ }^{1}$ Program Studi Manajemen Program Pascasarjana Universitas Bosowa \\ Email: muh.ichsan14@gmail.com
}

Diterima: 20 September 2021/Disetujui: 24 Desember 2021

\begin{abstract}
ABSTRAK
Penelitian ini bertujuan untuk mengetahui dan menganalisis pengaruh kompetensi, pengembangan karier, beban kerja, disiplin kerja terhadap kinerja pegawai pada Badan Kepegawaian dan Pengembangan Sumber Daya Manusia (BKPSDM) Kabupaten Jeneponto. Metode pengumpulan data melalui observasi, dokumen, penyebaran kuesioner, serta studi literatur dan teknik analisis data menggunakan analisis regresi linear berganda. Hasil penelitian menemukan bahwa kompetensi mempunyai pengaruh positif dan signifikan terhadap kinerja pegawai khususnya pada BKPSDM Kabupaten Jeneponto, pengembangan karier mempunyai pengaruh positif dan signifikan terhadap kinerja pegawai, beban kerja, mempunyai pengaruh negatif dan signifikan terhadap kinerja pegawai, disiplin kerja mempunyai pengaruh positif dan signifikan terhadap kinerja pegawai khususnya pada BKPSDM Kabupaten Jeneponto.
\end{abstract}

Kata Kunci: Kompetensi, Pengembangan Karier Beban Kerja, Disiplin Kerja dan Kinerja Pegawai

\begin{abstract}
This research aims to determine and analyze the effect of competence, career development, workload, work discipline on employee performance at the Personnel and Human Resources Development Agency (BKPSDM) Jeneponto Regency. Methods of data collection are through observation, documents, distributing questionnaires, and literature studies and data analysis techniques use multiple linear regression analysis. The results of the study show that competence has a positive and significant impact on employee performance, especially at BKPSDM Jeneponto Regency, career development has a positive and significant impact on employee performance, workload, has a negative and significant impact on employee performance, work discipline, and has a positive and significant impact on employee performance, especially at BKPSDM Jeneponto Regency.
\end{abstract}

Keywords: Competence, Workload Career Development, Work Discipline and Employee Performance

(c) (1) This work is licensed under Creative Commons Attribution License 4.0 CC-BY International license

\section{PENDAHULUAN}

Memahami pentingnya keberadaan sumber daya manusia di era globalisasi saat ini, menuntut setiap organisasi yang ingin bertahan dalam persaingan harus memiliki sumber daya manusia yang kompetitif. Sumber daya manusia dalam suatu organisasi/instansi pemerintah yang dalam hal ini pegawai berperan penting dalam memberikan pelayanan kepada masyarakat. Pegawai merupakan kunci penentu keberhasilan suatu organisasi, sehingga setiap pegawai dituntut untuk memiliki pengetahuan, keterampilan, dan kemampuan, serta semangat kerja tinggi agar dapat mencapai tujuan dan sasaran organisasi. Pencapaian tujuan organisasi, merupakan salah satu faktor penentu dalam peningkatan kinerja pegawai.

Kinerja pegawai merupakan suatu hal yang sangat penting dalam upaya untuk mencapai tujuan dari setiap organisasi. Kinerja akan selalu menjadi isu aktual dalam organisasi karena kinerja merupakan pertanyaan kunci 
terhadap efektivitas atau keberhasilan organisasi. Mangkunegara (2017) menyatakan bahwa kinerja adalah hasil kerja secara kualitas dan kuantitas yang dicapai oleh seorang pegawai dalam melaksanakan tugasnya sesuai dengan tanggung jawab yang diberikan kepadanya. Itulah sebabnya mengapa setiap organisasi perlu memperhatikan kinerja pegawainya karena baik atau buruknya suatu kinerja akan sangat mempengaruhi kelancaran organisasi.

Banyak faktor yang mempengaruhi determinan atau menentukan kinerja pegawai, dimana pada penelitian ini peneliti menentukan pada 4 faktor yakni : kompetensi, pengembangan karier, beban kerja dan disiplin kerja. Keempat faktor ini sangat penting dan merupakan determinan kinerja pegawai. Kompetensi mempengaruhi kinerja pegawai, hal ini sesuai dengan teori yang dikemukakan oleh Sudarmanto (2015) bahwa kompetensi menyebabkan pegawai dapat menghasilkan kinerja yang unggul, karena kompetensi yang dimiliki oleh pegawai akan berpengaruh terhadap hasil kerja. Setiap orang yang bekerja diharapkan mencapai kinerja yang tinggi sebagai hasil dari kegiatan unsur-unsur kemampuan yang dapat diukur dan terstandarisasi. Kemudian Lubis (2018) mengatakan bahwa kompetensi adalah pengetahuan, keterampilan, kemampuan atau karakteristik kepribadian seseorang yang secara langsung mempengaruhi kinerjanya. Penelitian Prayudiawan (2016) bahwa kompetensi memiliki dampak positif terhadap kinerja karyawan.

Faktor kedua yang menjadi determinan kinerja pegawai adalah pengembangan karier, Rivai (2018) menyatakan bahwa pengembangan karir merupakan proses peningkatan kemampuan kerja seorang pegawai yang mendorong meningkatnya kinerja dalam rangka mencapai karir yang diinginkan. Pengembangan karier sangat penting bagi suatu organisasi, karena karier merupakan kebutuhan yang harus terus dikembangkan dalam diri seorang pegawai sehingga mampu memotivasi pegawai untuk meningkatkan kinerjanya, dan organisasi memperoleh umpan balik berupa kinerja yang dihasilkan oleh pegawai tersebut. Napitupulu (2017), Balbed dan Sintaasih (2019) mendapatkan hasil penelitian bahwa pengembangan karir berpengaruh positif terhadap kinerja karyawan. Hal ini menyatakan bahwa semakin baik pengembangan karir maka semakin baik kinerja karyawan.

Selain kompetensi dan pengembangan karier, maka beban kerja berpengaruh terhadap kinerja pegawai, seperti yang dikemukakan oleh Nova Ellyzar (2017) bahwa beban kerja adalah sejumlah kegiatan yang harus diselesaikan oleh suatu unit organisasi atau pemegang jabatan secara sistematis dengan menggunakan teknis analisis jabatan, teknik analisis beban kerja, atau teknik manajemen lainnya dalam jangka waktu tertentu untuk mendapatkan informasi tentang efisiensi dan efektivitas kerja suatu unit organisasi. Ini menunjukkan bahwa jika beban kerja tinggi akan menyebabkan kinerja menurun, atau dapat dijelaskan bahwa semakin tinggi beban kerja yang diterima seorang pegawai akan mempengaruhi kinerja dari pegawai tersebut begitu juga sebaliknya. Penelitian Aris Hidayat Kurniawan (2019) bahwa beban kerja berpengaruh terhadap kinerja pegawai.

Selanjutnya disiplin kerja mempengaruhi kinerja pegawai, seperti teori yang dikemukakan oleh Hasibuan
(2019) bahwa kedisiplinan adalah kesadaran dan kesediaan seseorang mentaati semua peraturan perusahaan dan normanorma sosial yang berlaku. Kesadaran adalah sikap seseorang yang secara sukarela menaati semua peraturan dan sadar akan tugas dan tanggungjawabnya. Disiplin dibutuhkan untuk mempermudah dan melancarkan perusahaan dalam mencapai tujuannya, karena disiplin kerja yang tertanam pada setiap karyawan akan memberikan kesediaan mereka dalam mematuhi dan menjalankan aturan yang telah di tetapkan demi memajukan perusahaan. Peraturan sangat diperlukan untuk memberikan bimbingan dan penyuluhan bagi karyawan dalam menciptakan tata tertib yang baik di perusahaan. Dengan tata tertib yang baik, semangat kerja, moral kerja, efisiensi, dan efektivitas kerja karyawan akan meningkat. Penelitian Otong Karyono (2016) bahwa secara parsial disiplin kerja pegawai berpengaruh positif terhadap kinerja pegawai, hal ini mengindikasikan bahwa naik turunnya kinerja pegawai tergantung pada tinggi rendahnya disiplin kerja pegawai yang dimiliki para pegawai.

Penelitian ini dilakukan pada Badan Kepegawaian dan Pengembangan Sumber Daya Manusia Kabupaten Jeneponto (BKPSDM), sebagai salah satu instansi pemerintah yang siap membangun sinergitas dan peningkatan kinerja pemerintahan daerah, maka sangat dibutuhkan kinerja dari masing-masing pegawai untuk bersama-sama mendorong kemajuan daerah, namun permasalahan yang terjadi bahwa kinerja pegawai tidak maksimal. Hal ini tampak adanya aktivitas pegawai yang tidak produktif, masih ada pegawai yang terlambat masuk kantor dan pulang tidak tepat waktu. Ada kecenderungan pegawai menunda pekerjaan, menunggu perintah atasan sehingga hal ini menimbulkan beban kerja bagi pegawai, selain itu masih kurangnya kompetensi yang dimiliki oleh pegawai melalui pengetahuan, kemampuan dan keahlian pegawai khususnya dalam mengoperasikan komputer. Penyebab lainnya adalah kurangnya pengembangan karier atau promosi jabatan yang dilakukan oleh Pimpinan, hal ini dapat dilihat dari banyaknya pegawai honorer yang belum terangkat jadi PNS.

Dari permasalahan yang terjadi pada Badan Kepegawaian dan Pengembangan Sumber Daya Manusia (BKPSDM) Kabupaten Jeneponto, maka sepatutnya untuk meningkatkan kinerja pegawai maka faktor determinan kinerja pegawai perlu diperhatikan khususnya dalam hal kompetensi, pengembangan karier, beban kerja dan disiplin kerja. Peningkatan kinerja pegawai dalam sebuah instansi sangatlah penting, karena akan berdampak positif bagi instansi dan diharapkan mampu untuk meningkatkan kinerja pegawai dan kinerja organisasi.

\section{METODE}

\section{a. Jenis Penelitian}

Penelitian ini digolongkan sebagai penelitian penjelasan (eksplanatory) karena berupaya untuk menganalisis kinerja pegawai pada BKPSDM Kabupaten Jeneponto. Pendekatan dalam penelitian ini termasuk dalam penelitian kuantitatif, model penelitiannya adalah model survei dengan menggunakan instrument kuesioner.

b. Populasi dan Sampel 
Populasi adalah wilayah generalisasi yang terdiri atas: obyek/subyek yang mempunyai kualitas dan karakteristik tertentu yang ditetapkan oleh peneliti untuk dipelajari dan kemudian ditarik kesimpulannya (Sugiyono, 2016). Populasi dalam penelitian ini adalah pegawai BKPSDM Kabupaten Jeneponto Yang berjumlah sebanyak 44 orang pegawai. Sedangkan sampel adalah bagian dari jumlah dan karakteristik yang dimiliki oleh populasi tersebut (Sugiyono, 2016). Sehingga untuk menentukan jumlah sampel maka peneliti mengambil jumlah keseluruhan populasi yang ada yakni sebesar 44 orang maka teknik sampling yang digunakan adalah sampling jenuh. Sampling jenuh adalah teknik penentuan sampel bila semua anggota populasi digunakan sebagai sampel. Hal ini sering dilakukan bila jumlah populasi relatif kecil.

\section{c. Variabel Penelitian}

Variabel penelitian terdiri atas 2 (dua) macam yaitu : Variabel terikat (dependent variabel) atau variabel yang tergantung pada variabel lainya, dan variabel bebas (independent variabel) atau variabel yang tidak tergantung pada variabel lainya. Variabel yang digunakan dalam penelitian ini adalah :

1. Variabel Tidak Terikat (Bebas X)

Variabel tidak terikat (bebas) dalam penelitian ini meliputi:
a. Kompetensi (X1)
b. Pengembangan karier (X2)
c. Beban kerja (X3)
d. Disiplin kerja (X4)

2. Variabel Terikat (Y) Variabel terikat yaitu kinerja pegawai.

\section{d. Teknik Pengumpulan Data}

Untuk mendapatkan data yang diperlukan dalam rangka melakukan analisis terhadap pembuktian jawaban sementara atau hipotesis dari permasalahan yang dikemukakan maka peneliti menggunakan teknik pengumpulan data dengan cara sebagai berikut :

1. Observasi yaitu penelitian yang dilakukan dengan pengamatan secara langsung aktivitas atau kegiatan yang dilakukan pada BKPSDM Kabupaten Jeneponto

2. Dokumentasi, yaitu teknik pengumpulan data yang dilakukan dengan mempelajari dokumen-dokumen, laporan dan informasi yang berkaitan dengan penelitian.

3. Kuesioner dilakukan dengan cara membuat daftar pertanyaan yang dilengkapi dengan alternatif jawaban dan kemudian dibagikan kepada sejumlah responden untuk mendapatkan data yang dapat mendukung penelitian. Angket yang digunakan adalah angket terbuka. Penggunaan angket dimaksudkan agar semua jawaban yang diberikan responden lebih mudah untuk dinilai, karena semua alternatif jawaban sudah tersedia.

4. Studi Literatur

Studi literatur adalah cara yang dipakai untuk menghimpun data-data atau sumber-sumber yang berhubungan dengan kompetensi, pengembangan karier, beban kerja dan disiplin kerja pegawai terhadap kinerja pegawai. Studi literatur ini didapat dari berbagai sumber, jurnal, buku dokumentasi, internet dan pustaka.

\section{e. Jenis dan Sumber Data}

Jenis data yang digunakan dalam penelitian ini bersumber dari :

1. Data Kuantitattif, yaitu data yang diperoleh dan disajikan dalam bentuk angka-angka yang dipeoleh dari buku-buku, dokumen-dokumen dan referensi lainnya yang relevan dengan kajian yang diteliti.

2. Data Kualitatif, yaitu data yang berupa informasi atau keterangan-keterangan yang diperoleh dan disajikan dalam bentuk bukan angka.

Sedangkan sumber data yang digunakan dalam penelitian ini terdiri atas :

1. Data primer yakni data yang diperoleh dari hasil penelitian langsung di lapangan yang diperoleh melalui wawancara, penyebaran angket (daftar pertanyaan) yang di ajukan kepada responden.

2. Data sekunder, yakni data yang diperoleh dari tempat penelitian meliputi data yang dipublikasikan atau yang tidak dipublikasikan. Tentunya data ini berkaitan dengan lembaga dan yang berhubungan dengan penelitian ini.

\section{f. Teknis Analisis Data}

Metode ini merupakan metode analisis data di mana peneliti mengumpulkan, mengklasifikasikan, menganalisis dan menginterprestasi-kan data sehingga dapat memberikan gambaran yang jelas mengenai masalah yang diteliti. Metode analisis yang digunakan dalam penelitian ini adalah :

\section{Uji Kualitas Data}

a. Uji validitas

Uji validitas dan reliabilitas kuesioner dilakukan untuk menguji apakah suatu pertanyaan (kuesioner) layak digunakan sebagai instrument penelitian. Valid berarti instrumen tersebut dapat digunakan untuk mengukur apa yang seharusnya diukur. Validitas berhubungan dengan ketepatan alat ukur melakukan tugasnya mencapai sasaran. Pengukuran dikatakan valid jika mengukur tujuannya dengan nyata dan benar. Kriteria dalam menentukan validitas suatu kuesioner adalah sebagai berikut:

Jika $r_{\text {hitung }}>r_{\text {tabel }}$, maka pernyataan dinyatakan valid.

Jika $r_{\text {hitung }}<r_{\text {tabel }}$, maka pernyataan dinyatakan tidak valid.

b. Uji Reliabilitas

Reliabilitas menunjukkan akurasi dan konsistensi dari pengukurannya. Dikatakan konsisten jika beberapa pengukuran terhadap subyek yang sama diperoleh hasil yang tidak berbeda, Sugiyono (2016) Reliabel artinya data yang diperoleh melalui kuesioner hasilnya konsisten Kriteria dalam menentukan realiabilitas suatu kuesioner adalah sebagai berikut:

Jika $r_{\text {hitung }}>r_{\text {tabel }}$, maka kuesioner dinyatakan reliabel. 
Jika $\mathrm{r}_{\text {hitung }}<\mathrm{r}_{\text {tabel }}$, maka kuesioner dinyatakan tidak reliabel.

Uji validitas dan reliabilitas kuesioner penelitian ini menggunakan bantuan software SPSS 25.0 for windows.

\section{Uji Asumsi Klasik}

Sebelum melakukan analisis regresi, agar dapat perkiraan yang tidak bias dan efisiensi maka dilakukan pengujian asumsi klasik yang harus dipenuhi, yaitu :

\section{a. Uji Normalitas}

Tujuan uji normalitas adalah untuk mengetahui apakah distribusi sebuah data mengikuti atau mendekati distribusi normal. Uji normalitas dilakukan dengan menggunakan pendekatan Kolmogrov Smirnov. Dengan menggunakan tingkat signifikan 5\% maka jika nilai Asymp.sig. (2-tailed) di atas nilai signifikan 5\% artinya variabel residual berdistribusi normal (Situmorang dkk 2014).

b. Uji Heteroskedastisitas

Adanya varians variabel independen adalah konstan untuk setiap nilai tertentu variabel independen (homokedastisitas). Model regresi yang baik adalah tidak terjadi heteroskedatisitas. Heteroskedastisitas diuji dengan menggunakan uji Glejser dengan pengambilan keputusan jika variabel independen signifikan secara statistik mempengaruhi variabel dependen, maka ada indikasi terjadinya heteroskedastisitas. Jika probabilitas signifikannya di atas tingkat kepercayaan 5\% dapat disimpulkan modelregresi tidak mengarah adanya heteroskedastisitas. Heteroskedastisitas menguji terjadinya perbedaan variance residual suatu periode pengamatan ke periode pengamatan lainnya.

\section{c. Uji Multikolinearitas}

Artinya variabel independen yang satu dengan yang lain dalam model regresi berganda tidak saling berhubungan secara sempurna. Untuk mengetahui ada tidaknya gejala multikolinearitas dapat dilihat dari besarnya nilai Tolerance dan VIF (Variance Inflation Factor) melalui program SPSS. Tolerance mengukur variabilitas variabel terpilih yang tidak dijelaskan oleh variabel independen lainnya. Nilai umum yang biasa dipakai adalah nilai Tolerance $>1$ atau nilai VIF $<5$, maka tidak terjadi multikolinearitas (Situmorang dkk 2014).

\section{Analisis Regresi Linear Berganda}

Untuk menguji pengaruh antara variabel kompetensi, pengembangan ka-rier, beban kerja dan disiplin kerja terhadap kinerja pegawai dengan menggunakan analisis regresi linear berganda berdasarkan rumus yang dikemukakan oleh Sujarweni (2016) yaitu : $Y=\beta o+\beta_{1} X_{1}+\beta_{2} X_{2}+\beta_{3} X_{3}+\beta_{4} X_{4}+e$ Dimana:

$$
\begin{aligned}
& \mathrm{Y}=\text { Kinerja pegawai } \\
& \mathrm{X}_{1}=\text { Kompetensi } \\
& \mathrm{X}_{2}=\text { Pengembangan karier } \\
& \mathrm{X}_{3}=\text { Beban kerja } \\
& \mathrm{X}_{4}=\text { Disiplin kerja } \\
& \beta_{\mathrm{o}}=\text { Konstanta } \\
& \beta_{1}, \beta_{2}, \beta_{3}, \beta_{4}=\text { Koefisien regresi }
\end{aligned}
$$

\section{Pengujian Hipotesis}

Pengujian hipotesis dapat dilakukan dengan dua cara yaitu uji t (uji parsial) dan uji f (uji serempak) yang dapat diuraikan sebagai berikut :

a. Uji T

Uji t dilakukan untuk mengetagui pengaruh masingmasing variabel independent secara parsial terhadap variabel dependen. Uji $t$ dilakukan dengan membandingkan nilai probabilitas dan nilai standar dengan ketentuan:

Ho: $\beta=0$, berarti tidak ada pengaruh signifikan dari masing-masing variabel independent terhadap variabel dependen.

$\mathrm{Ha}: \beta>0$, berarti ada pengaruh yang signifikan dari masing-masing variabel dependen secara simultan.

b. Uji F

Pengujian ini dilakukan untuk mengetahui apakah semua variabel independent secara bersama-sama dapat berpengaruh terhadap variabel dependen. Cara yang digunakan adalah dengan membandingkan nilai nilai $\mathrm{F}_{\text {hitung }}$ dengan nilai $\mathrm{F}_{\text {tabel }}$ dengan ketentuan: Ho: $\beta=0$, berarti tidak ada pengaruh signifikan dari variabel independent terhadap variabel dependen.

$\mathrm{H} \alpha: \beta>0$, berarti ada pengaruh yang signifikan dari variabel independent terhadap variabel dependen.

5. Koefisien Determinasi. $\left(\mathrm{R}_{2}\right)$

Koefisien derterminasi menunjukkan seberapa besar kemampuan variabel independen dalam menerangkan variasi variabel dependen. Nilai R-Squares 0.75, 0.05, dan 0.25 menunjukkan bahwa model kuat. Setiap tambahan satu variabel independen, maka nilai $R$-Squares pasti akan meningkat (Latan dan Temalagi, 2013).

\section{HASIL DAN PEMBAHASAN}

\section{1) Pengaruh Kompetensi Terhadap Kinerja Pegawai}

Berdasarkan hasil olahan data regresi maka diperoleh koefisien regresi untuk variabel kompetensi sebesar 0,315, selain itu memiliki nilai probabilitas 0,011 $<0,05$, sehingga dapat dikatakan bahwa kompetensi mempunyai pengaruh yang positif dan signifikan terhadap kinerja pegawai. Artinya apabila kompetensi ditingkatkan maka akan mempengaruhi peningkatan kinerja pegawai.

Hasil penyebaran kuesioner maka diperoleh hasil tanggapan responden mengenai kompetensi yang dipersepsikan sudah tinggi. Temuan penelitian bahwa rata-rata pegawai memiliki kepatuhan yang tinggi dengan aturan-aturan/norma yang berlaku, tingginya rasa saling hormat menghormati antara pegawai dengan pegawai lainnya. Begitu pula dengan adanya keterampilan yang dimiliki oleh pegawai dalam mengerjakan tugasnya, setiap pegawai sudah memiliki pengetahuan dalam penyelesaian pekerjaan, serta setiap pegawai memiliki 
watak kepribadian yang baik dalam bekerja. Ini berarti bahwa semakin tinggi kompetensi yang dimiliki oleh setiap pegawai maka akan mempengaruhi peningkatan kinerja pegawai, sebagaimana teori yang dikemukakan oleh (2018) bahwa kompetensi adalah merupakan pengetahuan, keterampilan, kemampuan atau karakteristik kepribadian seseorang yang secara langsung mempengaruhi kinerjanya.

Kompetensi merupakan kemampuan seseorang yang dimiliki berdasarkan pengalaman atau latar belakang pendidikan yang dibawa pada saat ia bekerja pada suatu pekerjaan sehingga mampu menyelesaikan pekerjaan yang diberikan oleh pimpinan. Penelitian ini sejalan dengan penelitian yang dilakukan oleh Prayudiawan (2016), Ngebu (2018), dan Aprih Santoso (2020) hasil temuan bahwa kompetensi memiliki pengaruh positif dan signifikan terhadap kinerja pegawai, yang berarti bahwa semakin tinggi kompetensi maka kinerja pegawai akan semakin tinggi pula.

\section{2) Pengaruh Pengembangan Karier Terhadap Kinerja Pegawai}

Dari hasil persamaan regresi maka dapat dikatakan bahwa pengembangan karier mempunyai pengaruh yang positif, karena memiliki nilai koefisien regresi sebesar 0,282 , selain itu memiliki pengaruh yang signifikan, karena nilai probabiltas yang dihasilkan $0,010<0,05$. Pengembangan karier sangat penting bagi suatu organisasi, karena karier merupakan kebutuhan yang harus terus dikembangkan dalam diri seorang pegawai sehingga mampu memotivasi pegawai untuk meningkatkan kinerjanya, dan organisasi memperoleh umpan balik berupa kinerja yang dihasilkan oleh pegawai tersebut.

Berdasarkan hasil penyebaran kuesioner maka diperoleh temuan penelitian bahwa pengembangan karier yang dilakukan oleh kantor BKPSDM sudah berjalan dengan baik, hal ini dapat dilihat dari persepsi bahwa pegawai yang menonjol dalam kinerjanya lebih diprioritaskan untuk mendapatkan kenaikan jenjang karirnya, sehingga menyebabkan setiap pegawai berlomba-lomba untuk memberikan hasil kerja yang optimal. Adanya kesetiaan pegawai menjadi tolok ukur dalam pengembangan karir seorang pegawai, dimana kesetiaan pegawai dalam hal ini adalah diukur dari ketepatan waktu dalam penyelesaikan pekerjaan. Kemudian kesempatan untuk berkembang dalam karir terbuka bagi seluruh pegawai, dimana setiap pegawai mempunyai hak untuk dipromosikan walaupun hanya lulusan SMA, begitupula adanya peran manajemen sangat aktif dalam pengembangan karir pegawai. Sehingga dengan adanya pengembangan karier maka akan berpengaruh terhadap peningkatan kinerja pegawai, sebagaimana dikemukakan oleh Rivai (2018) bahwa pengembangan karir merupakan proses peningkatan kemampuan kerja seorang pegawai yang mendorong meningkatnya kinerja dalam rangka mencapai karir yang diinginkan.

Penelitian ini sejalan dengan penelitian yang dilakukan oleh Napitupulu (2017), Balbed dan Sintaasih (2019) mendapatkan hasil penelitian bahwa pengembangan karir berpengaruh positif terhadap kinerja karyawan. Hal ini menyatakan bahwa semakin baik pengembangan karir maka semakin baik kinerja karyawan.

\section{3) Pengaruh Beban Kerja Terhadap Kinerja Pegawai}

Dari hasil olahan data SPSS maka diperoleh nilai koefisien regresi untuk variabel beban kerja sebesar 0,113 serta memiliki nilai sig. sebesar 0,022 < 0,05, sehingga dapat dikatakan bahwa beban kerja mempunyai pengaruh positif dan signifikan terhadap kinerja pegawai pada BKPSDM Kabupaten Jeneponto. Hal ini sesuai dengan teori yang dikemukakan oleh Ellyzar (2017) bahwa beban kerja adalah sejumlah kegiatan yang harus diselesaikan oleh suatu unit organisasi atau pemegang jabatan secara sistematis dengan menggunakan teknis analisis jabatan, teknik analisis beban kerja, atau teknik manajemen lainnya dalam jangka waktu tertentu untuk mendapatkan informasi tentang efisiensi dan efektivitas kerja suatu unit organisasi. Penelitian Kurniawan (2019), dan Ginanjar, Muhammad Syukron, Indarto dan Djoko Santoso (2019) sejalan dengan penelitian ini didmana hasil temuan bahwa beban kerja berpengaruh signifikan terhadap kinerja pegawai. Ini menunjukkan bahwa jika beban kerja tinggi akan menyebabkan kinerja menurun, atau dapat dijelaskan bahwa semakin tinggi beban kerja yang diterima seorang pegawai akan mempengaruhi kinerja dari pegawai tersebut begitu juga sebaliknya.

\section{4) Pengaruh Disiplin Kerja Terhadap Kinerja Pegawai}

Dari hasil analisis olahan data dengan menggunakan program SPSS release 24, maka diperoleh koefisien regresi untuk disiplin kerja sebesar 0,350, selain itu memiliki nilai probabilitas $0,007<0,05$, sehingga hal ini dapat dikatakan bahwa disiplin kerja mempunyai pengaruh yang positif dan signifikan terhadap kinerja pegawai BKPSDM Kabupaten Jeneponto.

Berdasarkan hasil penyebaran kuesioner maka diperoleh temuan-temuan bahwa disiplin kerja sudah berjalan dengan baik, dimana dapat dilihat dari persepsi responden yang mengatakan bahwa setiap pegawai selalu mengerjakan tugas dengan tanggungjawab, hal ini dapat dilihat bahwa tidak ada lagi pekerjaan yang tertunda atau tidak dapat diselesaikan oleh pegawai. Kemudian setiap pegawai selalu menaati peraturan yang ditetapkan oleh pimpinan di tempat bekerja, ini dapat dilihat dari ketepatan waktu pegawai dalam masuk kantor sebelum apel pagi, setiap pegawai selalu menggunakan seragam kerja yang telah ditentukan oleh organisasi, dimana hari senin dan selasa memakai pakaian dinas warna putih, rabu dan kamis memakai pakaian coklat dan hari Jum'at 
memakai pakaian olahraga dan batik. Ini menunjukkan bahwa disiplin kerja yang diterapkan pada BKPSDM Kabupaten Jeneponto sudah berjalan dengan baik, sehingga mempengaruhi kinerja pegawai.

Hal ini sesuai dengan pendapat yang dikemukakan oleh teori yang dikemukakan oleh Hasibuan (2019) bahwa kedisiplinan adalah kesadaran dan kesediaan seseorang mentaati semua peraturan dan norma-norma sosial yang berlaku. Kesadaran adalah sikap seseorang yang secara sukarela menaati semua peraturan dan sadar akan tugas dan tanggungjawabnya.

Disiplin dibutuhkan untuk mempermudah dan melancarkan perusahaan dalam mencapai tujuannya, karena disiplin kerja yang tertanam pada setiap karyawan akan memberikan kesediaan mereka dalam mematuhi dan menjalankan aturan yang telah di tetapkan demi memajukan organisasi. Penelitian Otong Karyono (2016) sejalan dengan penelitian yang peneliti lakukan, bahwa secara parsial disiplin kerja pegawai berpengaruh positif terhadap kinerja pegawai, hal ini mengindikasikan bahwa naik turunnya kinerja pegawai tergantung pada tinggi rendahnya disiplin kerja pegawai yang dimiliki para pegawai.

\section{KESIMPULAN DAN SARAN}

Hasil penelitian dapat disimpulkan bahwa kompetensi mempunyai pengaruh positif dan signifikan terhadap kinerja pegawai khususnya pada BKPSDM Kabupaten Jeneponto. Pengaruh pengembangan karier terhadap kinerja pegawai, hasil penelitian dapat disimpulkan bahwa pengembangan karier mempunyai pengaruh positif dan signifikan terhadap kinerja pegawai pada BKPSDM Kabupaten Jeneponto. Pengaruh beban kerja terhadap kinerja pegawai, hasil penelitian dapat disimpulkan bahwa beban kerja mempunyai pengaruh negatif dan signifikan terhadap kinerja pegawai khususnya pada BKPSDM Kabupaten Jeneponto. Pengaruh disiplin kerja terhadap kinerja pegawai, hasil penelitian dapat disimpulkan bahwa disiplin kerja mempunyai pengaruh positif dan signifikan terhadap kinerja pegawai khususnya pada BKPSDM Kabupaten Jeneponto. Oleh karena itu maka saran-saran yang dapat diberikan sehubungan dengan hasil penelitian ini adalah : Kompetensi yang dimiliki oleh setiap pegawai sudah tinggi, namun masih perlu ditingkatkan lagi khususnya dalam hal menanamkan dalam diri setiap pegawai terkait dengan watak kepribadian yang baik dalam bekerja. Disarankan agar agar setiap pegawai lebih meningkatkan lagi prestasi kerjanya, karena dengan prestasi kerja yang dimiliki pegawai dapat memberikan kemudahan dalam pengembangan karir pegawai.

\section{DAFTAR PUSTAKA}

A.A Anwar Prabu Mangkunegara. 2017. Manajemen Sumber Daya Manusia Perusahaan. PT. Remaja Rosdakarya. Bandung.
Anies Khaqul Yaqinah, Aprih Santoso (2020) Telisik Determinan Kinerja Karyawan. Jurnal Pamator Volume 13 No 1, April 2020 Hlm. 81-94 http://journal. trunojoyo.ac.id/ pamator ISSN: 18297935.

Aris Hidayat Kurniawan (2019), Determinan Kinerja Pegawai: Peran Beban Kerja, Motivasi dan Kepuasan Kerja Jurnal Riset Manajemen dan Bisnis (JRMB) Fakultas Ekonomi UNIAT Vol. 4, No.2, Juni 2019: 287 - 294 P-ISSN 2527-7502 E-ISSN 2581-2165

Balbed, Ammar dan Desak Ketut Sintaasih, 2019. Pengaruh Pengembangan Karier terhadap Kinerja Karyawan melalui Pemediasi Motivasi Kerja Karyawan. E-Jurnal Manajemen, Vol. 8, No. 7, ISSN: 2302-8912

Danang Sunyoto. 2015. Manajemen dan Pengembangan Sumber Daya Manusia. Penerbit : Center for Academic Publishing Service. Yogyakarta

----_coriaku Keorganisasian, Dilengkapi Intervensi Pengembangan Organisasi, cetakan pertama, Penerbit : Center for Academic Publishing Service. Yogyakarta.

Edison, Emron. Yohny anwar, Imas komariyah. 2016. Manajemen Sumber Daya Manusia. Penerbit : Alfabeta, Bandung.

Hasibuan, S.P. Malayu. 2019. Manajemen Sumberdaya Manusia, Edisi Revisi. Cetakan keduapuluh tiga, Penerbit : Bumi Aksara, Jakarta.

Hepi Prayudiawan, (2016) Determinan Yang Mempengaruhi Kinerja Karyawan Pada Bank BRI Cabang Kramat Jati Jakarta Esensi: Jurnal Bisnis dan Manajemen Volume 6 (2), Oktober 2016 PISSN: 2087-2038; E-ISSN:2461-1182 Halaman 173180.

Kurniawan, Aris Hidayat, Sri Lestari Prasilowati dan Suyanto (2019), Determinan Kinerja pegawai: Peran beban kerja, motivasi dan kepuasan, Jurnal Riset Manajemen dan Bisnis (JRMB) Fakultas Ekonomi UNIAT, Vol.4, No.2, Juni 2019: 287-294P-ISSN 2527-7502 E-ISSN 2581-2165.

Latan, Hengky dan Selva Temalagi, 2013. Analisis Multivariate Teknik dan Aplikasi Menggunakan Program IBM SPSS 20,0. Penerbit : Alfabeta. Bandung

Lubis Yusniar, dkk, 2018, Manajemen dan Riset Sumber Daya Manusia, cetakan pertama, Penerbit : Alfabeta, Bandung.

Napitupulu, S. (2017). The impact of career development on employee performance: an empirical study of the public sector in Indonesia. International Review of Public Administration. 3(22): 276-299.

Nova Ellyzar, Mukhlis Yunus, Amri. 2017. Pengaruh Mutasi Kerja, Beban Kerja, dan Konflik Interpersonal Terhadap Stress Kerja Serta Dampaknya Pada Kinerja Pegawai BPKP Perwakilan Provinsi Aceh.Jurnal Magister Manajemen. Fakultas Ekonomi dan Bisnis Unsyiah. Vol 1. No. 1: Hal 35-45. 
Rivai, Veithzal, 2018, Manajemen Sumber Daya Manusia, Untuk Perusahaan, edisi ketiga, cetakan kedelapan, Penerbit : Raja Grafindo, Jakarta.

Sudarmanto. 2015. Kinerja dan Pengembangan Kompetensi SDM, edisi tiga. Penerbit : Pustaka Pelajar. Yogyakarta.

Sujarweni Wiratna, V. 2016, Kupas Tuntas Penelitian Akuntansi dengan SPSS, Penerbit : Pustaka Baru Press, Yogyakarta

Sugiyono. 2016. Metode Penelitian Kuantitatif, Kualitatif dan R\&D Penerbit : Alfabeta Bandung.

Situmorang dan Lufti, 2014. Analisis Data untuk Riset Manajemen dan Bisnis, USU Press, Medan.

Wilfridus Djaga Ngebu (2018) Pengaruh Kompetensi dan Penempatan Pegawai Terhadap Kepuasan dan Kinerja Pegawai. Jurnal Ekonomi dan Bisnis, Universitas Udayana. ISSN : 2337-3067

Wibowo, 2016. Manajemen Kinerja, Edisi Kelima, Penerbit : Rajagrafindo Persada, Jakarta 